\title{
TINJAUAN YURIDIS PENGAJUAN PERMOHONAN PENINJAUAN KEMBALI PADA PERKARA PIDANA DALAM SISTEM HUKUM INDONESIA
}

\author{
I Made Widi Adi Peremana, A. A. Sagung Laksmi Dewi, Ni Made Sukaryati Karma \\ Fakultas Hukum Universitas Warmadewa Denpasar-Bali, Indonesia
}

\begin{abstract}
Abstrak
Kajian penelitian ini adalah pengajuan permohonan peninjauan kembali pada perkara pidana dalam sistem hukum indonesia yang menjadi polemik pasca di keluarkannya Putusan Mahkamah Konstitusi Nomor 34/XIPUU/2013 dan Surat Edaran Mahkamah Agung (SEMA) Nomor 7 Tahun 2014 tentang Pengajuan Permohonan Kembali Dalam Perkara Pidana. Adapun tujuan penelitian yang ingin di capai dalam hal ini adalah pengaturan upaya hukum peninjauan kembali di Indonesia dan prosedur pengajuan permohonan peninjauan kembali dalam sistem Indonesia. Peneliti menggunakan metode pendekatan yuridis normatif atau penelitian kepustakaan atau penelitian hukum doktrinal yang dapat diartikan sebagai penelitian hukum dengan cara meneliti bahan pustaka dan bahan sekunder. Penelitian ini menggambarkan bahwa Pengaturan terhadap peninjauan kembali dalam sistem hukum di Indonesia didasarkan dari berbagai peraturan yaitu Undang-undang Nomor 8 Tahun 1981 tentang Kitab Undang-undang Hukum Acara Pidana, Undang-Undang No. 3 Tahun 2009 tentang Mahkamah Agung, Undang-Undang No. 48 Tahun 2009 tentang Kekuasaan Kehakiman, Surat Edaran Mahkamah Agung Republik Indonesia No. 7 Tahun 2014 tentang Peninjauan Kembali Dalam Perkara Pidana dan Pengajuan peninjauan kembali saat ini adalah mengacu pada ketentuan pada Surat Edaran Mahkamah Agung Republik Indonesia No. 7 Tahun 2014 tentang Peninjauan Kembali Dalam Perkara Pidana.
\end{abstract}

Kata kunci: Hukum; Peninjauan kembali; Pengaturan

\begin{abstract}
The study of this research is the submission of requests for reconsideration in criminal cases in the Indonesian legal system which became a polemic after the issuance of the Constitutional Court Decision Number 34 / XIPUU / 2013 and Circular Letter of the Supreme Court (SEMA) Number 7 of 2014 concerning Submission of Reappeals in Cases Criminal. The research objectives to be achieved, in this case, are the regulation of legal reconsideration efforts in Indonesia and the procedure for submitting a request for review in the Indonesian system. Researchers use a normative juridical approach or library research or doctrinal legal research which can be interpreted as legal research by examining library materials and secondary materials. This study illustrates that the regulations for reconsideration in the legal system in Indonesia are based on various regulations, namely Law Number 8 of 1981 concerning the Criminal Procedure Code, Law No. 3 of 2009 concerning the Supreme Court, Law no. 48 of 2009 concerning Judicial Power, Circular Letter of the Supreme Court of the Republic of Indonesia No. 7 of 2014 concerning Review of Criminal Cases and Submission of Reconsiderations at this time refers to the provisions of the Circular Letter of the Supreme Court of the Republic of Indonesia No. 7 of 2014 concerning Reconsideration in Criminal Cases.
\end{abstract}

Keywords: Law; Judicial review; Settings

\section{PENDAHULUAN}

Undang-undang Nomor 1 Tahun 1981 Kitab Undang-undang Hukum Acara Pidana memiliki tujuan untuk menjalankan hukum pidana dalam KUHP dengan tetap memperhatikan hak asasi, tujuan yang dimaksud adalah bagian dari pembahasan yang menjelaskan teori Negara Hukum (rechstaat) yang berlaku di Negara Republik Indonesia. Undang-undang Nomor 8 Tahun 1981 tentang Kitab Undang-undang Hukum Acara Pidana, yang telah berlaku sampai saat ini dalam pelaksanaannya telah terjadi berbagai perkembangan serta perubahan diantaranya perubahan terhadap peraturan pada Pasal yang di Kitab Undang-undang Hukum Acara Pidana telah dilakukan pengujian perundangundangan (Judicial review) pada lembaga peradilan yang berwenang yaitu Mahkamah Konstitusi Republik Indonesia. Dalam putusannya terhadap salah satu pasal yang diputuskan adalah dengan 
amar putusan salah satu ketentuan Pasal tidak dapat diberlakukan dan terhadap permohonan yang lainnya oleh Mahkamah diputuskan dan dinyatakan di tolak. Putusan Mahkamah Konstitusi ini tentunya berimplikasi dan berdampak pada penegakan hukumnya terutama pada ketentuan dalam Kitab Undang-undang Hukum Acara Pidana yang telah diputuskan dengan tidak memiliki kekuatan hukum yang mengikat tersebut.

Akibat yang timbul pada ketentuan dalam Undang-undang Nomor 8 tahun 1981 tentang Kitab Undang-undang Hukum Acara Pidana yang oleh Mahkamah Konstitusi dinyatakan menerima permohonan Penggugat pada proses pengujian tersebut diatas secara hukum ketatanegaraan proses hukum khususnya dalam hal litigasi dalam hal ini adalah terkait dengan hak hukum untuk mengajukan hukum Peninjauan kembali (PK). Peninjauan Kembali dianggar sesuatu yang penting karena peninjauan kembali mengatur mengenai peraturan upaya hukum luar biasa pada upaya hukum Peninjauan Kembali. Dalam hukum pidana yaitu pada Kitab Undang-undang Hukum Acara Pidana proses peninjauan kembali telah diatur pada Kitab Undang-undang Hukum Acara Pidana yang berlaku di Indonesia dan hal ini merupakan langkah hukum yang masuk dalam kategori langkah hukum luar biasa. Ketentuan ini adalah langkah hukum yang mengelola proses tentang proses dan mengajukan upaya hukum peninjauan kembali terhadap suatu putusan pengadilan yang telah dinyatakan berkekuatan hukum tetap dan/ atau tidak dapat upaya hukum biasa lagi. Dengan demikian proses dalam langkah luar biasa itu memberikan hak kepada pelaku yang telah di proses dan dihukum sehingga menjadi terpidana, ternyata berdasarkan bukti- bukti baru yang ditemukan secara signifikan setelah diteliti ternyata yang bersangkutan tidak mempunyai kesalahan atau tindakannya tidak merupakan tindakan melanggar hukum atau dalam putusan ternyata ternyata dilakukan bukan oleh terpidana.

Sesuai peraturan upaya hukum peninjauan kembali hanya dapat diajukan satu kali. Peraturan ini terdapat dalam Pasal 268 Kitab Undang-undang Hukum Acara Pidana KUHAP yang menyatakan bahwa peninjauan kembali atas putusan yang telah berkekuatan tetap hanya boleh diajukan satu kali saja. Peraturan yang ada pada Pasal 268 KUHAP tersebut oleh pihak yang dirugikan diajukan Judicial Review dan dalam putusan uji materiil pada MK No. perkara 34/PPU-XI/2013 diputuskan pasal peninjauan kembali tidak memiliki kekuatan hukum mengikat, hal ini mempunyai arti bahwa upaya hukum peninjauan kembali dapat diajukan dan diproses lebih dari satu kali permohonan kepada Mahkamah Agung dan terhadap kasus atau perkara yang sama baik dalam perkara hukum perdata maupun perkara hukum pidana.

Keputusan yang dikeluarkan mahkamah dalam perkembangannya ternyata menimbulkan dan mempunyai efek yang luar biasa pada dinamika hukum dan dalam tindakan pada bidang hukum khususnya dalam rangka menegakkan hukum pidana hal ini karena masih banyak putusan yang mempunyai kekuatan hukum tetap yang berupaya mengajukan peninjauan kembali dan tentu mengurangi nilai kepastian hukumnya. Mengatasi permasalahan hukum tersebut Mahkamah Agung berdasarkan kewenangannya pada tahun 2014 telah mengeluarkan Surat Edaran (SEMA) No. 7 Tahun 2014 tentang Pengajuan Permohonan Peninjauan Kembali. Dengan peraturan yang dikeluarkan oleh lembaga yudisial tertinggi yaitu MA menerbitkan SEMA Nomor 7 Tahun 2014 tentang Pengajuan Permohonan Peninjauan Kembali dalam Perkara Pidana tersebut ternyata memunculkan permasalahan. SEMA tersebut kembali pada peraturan sebelumnya yaitu proses permohonan PK (Peninjauan Kembali) dalam tindak pidana hukum pidana hanya dapat dimohon satu kali sama seperti pada saat peraturan sebelum diajukan Judicial Review.

Dengan dikeluarkannya SEMA tersebut terjadi permasalahan secara hukum antara Putusan Mahkamah Konstitusi No. 34/PUU-XI/2013 yang memutuskan bahwa upaya hukum PK dapat dimohonkan lebih dari satu kali dengan dasar hukum Putusan Mahkamah Konstitusi melalui pembatalan Pasal 268 ayat (3) KUHAP yang membatasi pengajuan PK hanya satu kali. SEMA yang dikeluarkan tersebut secara hukum MA telah tidak tunduk pada Putusan Mahkamah dan hal ini cenderung bertentangan dengan asas-asas serta teori hukum pembentukan peraturan perundangundangan yang berlaku di Indonesia. Atas dasar hal tersebut maka secara peraturan terjadi kekacauan dalam hal sistem hukum yang saat ini diberlakukan di Indonesia.

Terkait dengan penelitian sebelumnya oleh (Kusumawati, 2015) bahwa dalam Pasal 263 KUHP menjelaskan landasan hukum bagi jaksa untuk mengajukan permintaan peninjauan kembali perkara pidana. Sesuai ketentuan Pasal 263 ayat (3) KUHAP tersebut, jaksa dapat mengajukan 
permintaan peninjauan kembali, dengan syarat bahwa dalam putusan yang diminta peninjauan kembali itu, suatu perbuatan yang didakwakan telah dinyatakan terbukti akan tetapi tidak diikuti dengan pemindanaan.

Berdasarkan hal-hal tersebut, maka penulis dapat merumuskan beberapa permasalahan yaitu: Bagaimanakah pengaturan upaya hukum peninjauan kembali di Indonesia serta bagaimanakah pengajuan permohonan peninjauan kembali dalam sistem hukum Indonesia. Adapun tujuan penelitian yang ingin di capai dalam hal ini adalah pengaturan upaya hukum peninjauan kembali di Indonesia dan prosedur pengajuan permohonan peninjauan kembali dalam sistem Indonesia.

\section{METODE PENELITIAN}

Dalam penelitian ini, peneliti memakai pendekatan yuridis normatif/ penelitian kepustakaan/ penelitian yang didasarkan pada doktrin yaitu penelitian yang dilaksanakan dengan meneliti data/ bahan primer serta data/ bahan sekunder (Mamudji, 2007) . Dikategorikan Penelitian normatif karena penulisan hukum ini didasarkan pada penelitian terhadap asas-asas hukum yang berlaku kemudian dihubungkan dengan pelaksanaan terhadap asas-asas hukum dimaksud. Jenis penelitian normatif yaitu penelitian ilmiah yang bertujuan untuk menemukan kebenaran berdasarkan logika keilmuan hukum dari sisi normatifnya. Penelitian hukum normatif sendiri berfokus pada penelitian pada asasasas hukum. Sedangkan pendekatan masalah yang digunakan secara yuridis yaitu dengan meninjau peraturan yang berhubungan dengan permasalahan.

\section{HASIL DAN PEMBAHASAN}

\section{Pengaturan Upaya Hukum Peninjauan Kembali di Indonesia}

Indonesia merupakan negara hukum, hal ini mempunyai arti bahwa segala tindakan pemerintah maupun rakyat selalu berdasarkan hukum yang berlaku, guna menghindari adanya tindakan yang sewenang-wenang dari penyelenggaran negara terhadap segala prilaku masyarakat yang dipimpin. Negara hukum berdasarkan atas hal tersebut dapat disimpulkan bahwa pemerintah telah menjunjung tinggi adanya hak-hak setiap manusia yang sering disebut dengan Hak Asasi Manusia (Reksodiputro, 1994).

Penegakan hukum adalah upaya untuk mencapai penegakkan peraturan- peraturan hukum yang berlaku serta mencapai hal-hal yang terkandung didalam peraturan-peraturan tersebut. Hal ini mempunyai arti bahwa para penegak hukum yang diberikan wewenang harus mempunyai pemahaman bahwa dasar hukum yang menjadi dasar peraturan perundang-undangan yang berlaku harus ditegakkan dengan baik, hal ini berkaitan erat terhadap berbagai permasalahan yang terjadi dalam proses pembuatan perundang-undangan pada lembaga yang berwenang.

Dalam hal penegakan hukum terdapat mekanisme hukum yang disebut dengan upaya hukum, dimana upaya hukum adalah hak seseorang baik terdakwa dan/atau aparat penegak hukum yang dapat ditempuh apabila ada pihak yang menganggap bahwa putusan yang diberikan oleh pengadilan tidak mencerminkan keadilan dan cenderung bertindak sewenang-sewenang karena langkah hukum ini adalah hak maka hak yang dimiliki itu dapat digunakan oleh seseorang yang berhadapan dengan hukum atau dapat dipergunakan oleh aparat penegak hukum dalam hal ini Jaksa/ Penuntut Umum. Dilain pihak, jika dalam perkembangannya keinginan untuk memohonkan upaya hukum tersebut digunakan oleh seseorang dan aparat penegak hukum yang berwenang, maka pengadilan wajib menerima proses hukum yang diajukan tersebut. Hal tersebut di atas telah sesuai dengan ketentuan pada peraturan perundang-undangan yaitu dalam Pasal 67 Kitab Undang-undang Hukum Acara Pidana yang menyatakan bahwa terdakwa atau aparat penegak hukum mempunyai hak untuk mengajukan upaya hukum banding atas keputusan pengadilan negeri yang memproses paling pertama, pengecualian untuk keputusan pada pengadilan negeri dengan amar putusan membebaskan terdakwa atau terdakwa dinyatakan lepas dari segala tuntutan oleh penegak hukum yang berkaitan dengan kurang tepatnya penerapan hukum oleh penegak hukum dan putusan pengadilan dalam hukum acara cepat.

Hukum acara pidana telah membagi langkah hukum itu ada dua yaitu langkah hukum yang disebut langkah hukum biasa dan langkah hukum yang dinyatakan luar biasa, upaya hukum biasa itu adalah proses hukum pada pemeriksaan banding dan pemeriksaan kasasi dan upaya hukum yang sering disebut degan upaya hukum luar biasa yaitu upaya hukum Peninjauan kembali (PK) seperti yang dibahas dalam jurnal ini dan upaya hukum kasasi demi kepentingan hukum. 
Dalam sistem hukum acara di Indonesia, suatu perkara yang telah diputus dengan amar putusan yang tidak dapat diajukan upaya hukum secara biasa lagi artinya merupakan putusan bersifat tetap, atas dasar kepastian hukum tidak dapat dibuka untuk di proses lagi. Proses hukum tidak dapat dilaksanakan tanpa akhir atau tanpa putusan penyelesaian, tidak terbatas pada hukum dalam bidang perdata atau hukum dalam bidang pidana. Secara asas hukum Hal ini disebut dengan istilah nebis in idem, hal ini berarti tidak adanya dasar hukum untuk memproses perkara ini lagi. Tujuan adanya asas hukum ini adalah memberikan kepastian dalam penegakan hukum yang dilaksanakan di Republik Indonesia. Langkah hukum peninjauan kembali merupakan langkah hukum yang masuk kategori langkah hukum hukum luar biasa, yang berarti langkah hukum tersebut adalah menyimpang dari langkah hukum biasa yaitu banding dan kasasi.

Upaya hukum banding dan kasasi merupakan upaya hukum yang diajukan terhadap putusan pengadilan yang belum berkekuatan hukum tetap dengan kata lain masih diberikan ruang upaya hukum biaya terhadap putusan ini, langkah hukum yang di tempuh terhadap putusan yang belum berkekuatan tetap adalah dengan mengajukan upaya hukum banding/ kasasi atas semua putusan baik dari terdakwa maupun penuntut umum. Upaya hukum PK (Peninjauan Kembali) disebut langkah hukum luar biasa karena langkah hukum yang ditempuh dalam proses ini adalah langkah hukum terhadap putusan yang telah memiliki kekuatan hukum tetap dan/atau langkah hukum diajukan ketika upaya hukum biasa telah tidak dapat dilakukan. Secara hukum segala putusan pengadilan yang telah berkekuatan hukum tetap atau upaya hukum biasa terlampaui, demi kepastian hukum harus dihormati dan dilaksanakan oleh seluruh pihak. Langkah hukum peninjauan kembali digunakan untuk menarik kembali atau menolak putusan hakim yang telah mempunyai kekuatan hukum tetap (Litbang, 2006).

Hukum acara yang ada di Indonesia berlaku sejak dibuat Undang-undang Nomor 8 tahun 1981 tentang Kitab Undang-undang Hukum Acara Pidana, sebelum tahun 1981 secara hukum acara tidak ada satu dasar hukum yang mengatur tentang Peninjauan Kembai (Hamzah, 2001). Pengaturan Upaya Hukum Peninjauan kembali dalam Undang-undang Nomor 8 Tahun 1981 tentang Kitab Undang-undang Hukum Acara Pidana pada bagian Kedua Bab XVIII tentang upaya hukum luar biasa mulai dari Pasal 263 KUHAP sampai dengan Pasal 269.

\section{Prosedur Pengajuan Permohonan Peninjauan Kembali dalam Sistem Indonesia}

Pengaturan langkah hukum Peninjauan kembali pada Undang-undang Nomor 8 tahun 1981 tentang Kitab Undang-undang Hukum Acara Pidana secara teori hukum disebut dengan upaya hukum luar biasa, dasar hukum upaya hukum ini diatur dalam Pasal 263 sampai dengan Ketentuan Pasal 269 dan upaya hukum luar biasa yang lain sebagaimana disebut dengan kasasi demi kepentingan hukum secara hukum diatur dalam ketentuan Pasal 259 sampai dengan Pasal 262, ketentuan hukum sebagaimana dalam Pasal 263 ayat (1) Undang-undang Nomor 8 Tahun 1981 tentang Kita Undang-undang Hukum Acara Pidana telah mengatur tentang upaya hukum biasa terhadap putusan bebas terhadap putusan pengadilan yang telah memperoleh kekuatan hukum tetap dapat terpidana atau ahli warisnya.

Di lain pihak dalam Pasal 4 ayat (1) Perma Nomor 1 tahun 1969 tentang Peninjauan kembali keputusan pengadilan yang telah memperoleh kekuatan hukum yang tetap, pada prinsipnya menyatakan bahwa upaya hukum peninjauan kembali terhadap putusan yang diproses dengan hukum pidana dan telah memperoleh kekuatan hukum yang tetap harus diajukan sendiri oleh seseorang yang telah menyandang status sebagai terpidana, pihak yang dianggap mempunyai kepentingan, dan oleh penuntut umum melalui Jaksa Agung.

Dalam perkembangan hukum acara pidana seorang terpidana mantan Ketua Komisi Pemberantasan Korupsi bernama Antasari Azhar telah mengajukan Judicial Review kepada Mahkamah Konstitusi terkait dengan peninjauan kembali hanya dilakukan satu kali, Antasari mempunyai pandangan bahwa peninjauan kembali hanya boleh diajukan satu kali telah membatasi keadilan yang diberikan kepada seseorang dan hal ini dianggap telah bertentangan dengan UUD NRI 1945 yang menjunjung tinggi hak asasi manusia. Keberadaan upaya hukum peninjauan kembali tersebut sebagai peraturan hukum yang dianggap langkah hukum luar biasa pada penegakan hukum pidana dan memberikan peluang adanya tindakan perbaikan dan didapatkan adanya kesalahan dalam tahap menunjukkan bukti pada persidangan yang dilaksanakan secara hirarki dimulai dari peradilan 
negeri atau pada tingkat pertama, pada tingkat kedua atau tingkat banding, hingga pada Mahkamah Agung pada tingkat kasasi.

Melalui proses persidangan pada Mahkamah Konstitusi, Mahkamah Konstitusi telah memutuskan dan menerbitkan putusan Mahkamah Konstitusi terhada pengujian upaya hukum peninjauan kembali menyakan pasal yang menjadi obyek pengujian secara hukum tidak berlaku sebagai dasar hukum dalam mengajukan upaya hukum peninjauan kembali, dengan dikeluarkannya putusan Mahkamah Konstitusi Nomor 34/PUU-XI/2013 maka peninjauan kembali dapat diajukan sekali atau lebih bahkan tidak terbatas. Secara teori hukum unsur keadilan merupakan hak setiap orang tanpa memandang status, suku serta keadaan seseorang ketika di putuskan dalam hukum pidana, pendapat ini didasarkan pula pada alasan bahwa bukti baru dapat ditemukan tidak saja pada proses persidangan tetapi setelah putusan dijatuhkan kemudian mempunyai kekuatan hukum tetap. Sebagai sebuah lembaga peradilan, peran strategis Mahkamah Konstitusi dalam mengawal dan menjamin pelaksanaan prinsip- prinsip dan norma yang terkandung dalam konstitusi sebagai norma tertinggi di dalam penyelenggaraan kehidupan bernegara (Zoelva, 2009).

Majelis Hakim pada Mahkamah Konstitusi melalui putusannya terhadap pengujian upaya hukum peninjauan kembali pada KUHAP menjatuhkan keputusan jika pasal yang terkandung dalam Kitab Undang-undang Hukum Acara Pidana tentang peninjauan kembali diputuskan tidak berlaku dan tidak dapat dijadikan dasar hukum untuk mengajukan upaya hukum, tidak berlakunya pasal ini karena tidak sesuai dengan ketentuan pada Konstitusi Negara Republik Indonesia. Putusan ini dibuat dan diputuskan dalam rapat Permusyawaratan Majelis Hakim Mahkamah Konstitusi Pada tanggal 22 juli 2013 dan dikeluarkan pada sidang pleno Mahkamah Konstitusi pada tanggal 6 Maret 2014.

Berdasarkan Putusan Mahkamah Konstitusi tentang pasal upaya hukum pengajuan upaya hukum pada KUHAP yang telah dikeluarkan tersebut, jika dilihat dari teori hukum putusan Mahkamah Konstitusi maka dalam putusanya Mahkamah Konstitusi menggunakan model putusan yang secara hukum membatalkan dan menyatakan tidak berlaku. Dalam Putusan MK No. 34/PUU$\mathrm{XI} / 2013$ dengan amar putusannya telah membatalkan dan menyatakan tidak berlaku terhadap peraturan perundang-undangan yaitu pasal 268 ayat (3) Kitab Undang-undang Hukum Acara Pidana.

Model putusan pengadilan pada Mahkamah Konstitusi ini secara rinci menyatakan bahwa suatu peraturan perundang-undangan yang telah diuji dinyatakan bertentangan dengan Undangundang Dasar 1945 baik secara keseluruhan maupun sebagian isi pasalnya, sejak diucapkan oleh Majelis Hakim Pada persidangan Mahkamah Konstitusi maka secara hukum Undang-undang tersebut dinyatakan tidak memiliki kekuatan hukum mengikat lagi (Zoelva, 2009). Sesuai dengan teori hukum yang berlaku telah dinyatakan bahwa Putusan Mahkamah Konstitusi bersifat final and binding, hal ini berarti putusan Mahkamah Konstitusi sejak diucapkan secara langsung mempunyai kekuatan hukum tetap dan tidak ada upaya hukum yang apapun yang dapat ditempuh.

Dengan demikian agar hal ini tidak menimbulkan kegaduhan didunia hukum maka penting bagi Mahkamah Agung untuk segera menentukan dan menyusun peraturan yang memadai sehubungan dengan adanya putusan Mahkamah Konstitusi No. 34/PUU-XI/2013 melalui peraturan yang diberlakukan syarat dan kriteria pengajuan Peninjauan Kembali pada Mahkamah Agung guna menciptakan nilai kepastian hukum, keadilan dan kemanfaatan dimasyarakat.

Meskipun secara hukum acara pada umumnya suatu putusan pengadilan bersifat kasuistis yang berarti hanya berlaku bagi pihak yang sedang berperkara saja, akan tetapi terhadap putusan pengadilan yang obyek perkaranya adalah pengujian peraturan perundang-undangan yang berlaku tidak hanya bagi para pihak yang sedang berperkara dan dimohonkan agar dapat dilakukan pengujian terhadap suatu peraturan perundang-undangan, tetapi berlaku juga untuk masyarakat dari latar belakang yang berbeda. Teori hukum Erga omnes sering dipergunakan dalam teori hukum untuk memberikan penjelasan kepada sesama warga negara mengenai kewajiban dan hak.

Putusan yang telah diputuskan oleh Mahkamah Konstitusi dalam perkara pengujian atas suatu undang-undang dan undang-undang tersebut telah mempunyai mengikat terhadap semua warga Negara Indonesia, maka dengan adanya putusan yang menyatakan suatu Undang-undang tidak mempunyai kekuatan hukum mengikat, secara hukum undang-undang tersebut tidak lagi memiliki kekuatan hukum sama sekali. Tidak mengikat bukan hanya pada para pihak yang berperkara atau menjadi pemohon pengujian undang-undang berlaku juga bagi seluruh warga Negara (Sunggono, $\underline{2013})$. 
Surat Edaran Mahkamah Agung secara hukum hanya dapat ditujukkan dan berlaku kepada: ketua pengadilan, hakim, panitera pengadilan, ataupun pejabat lainya yang berada di lingkungan peradilan yang berada dibawah Mahkamah Agung yaitu Peradilan Umum (Pengadilan Negeri), Peradilan Agama, Peradilan Militer, Peradilan Tata Usaha Negara sehingga SEMA merupakan kebijakan yang dapat mengatur ke dalam/ internal. Apabila ditinjau dalam dalam ilmu perundang-undangan, terdapat teori yang disebut oleh (Kalsen, 2010) yaitu Stufenbau Theory, teori ini menyatakan bahwa peraturan perundang-undangan yang secara hirarki ada dibawahnya tidak bertentangan dengan peraturan perundang-undangan yang berada diatas tingkatannya (Kalsen, 2010).

Dilain pihak putusan uji materiil Nomor 34/PUU-XU/2013 terhadap pasal 268 ayat (3) Undang-undang Nomor 8 Tahun 1981 dinyatakan tidak memiliki hukum tetap tersebut sesungguhnya dapat diselesaikan melalui peraturan hukum yaitu pada ketentuan Undang-undang Kekuasaan Kehakiman dan Undang-undang Mahkamah Agung yang sama-sama dalam rumusan pasalnya menjelaskan dan memiliki materi muatan tentang peninjauan kembali, secara lebih detail dinyatakan bahwa upaya hukum terhadap proses hukum peninjauan kembali yang dilakukan oleh seorang narapidana hanya dapat dilakukan satu kali.

Dasar hukum dari hal-hal tersebut adalah atas dasar kedua dasar hukum tersebut diatas secara peraturan perundang-undangan berada setingkat yakni merupakan Undang-undang yang sesuai baik antara Undang-undang yang lain atau terhadap peraturan yang berada diatasnya, sehingga dengan dasar tersebut sesungguhnya Mahkamah Agung sekiranya tidak semestinya mengeluarkan Surat Edaran Mahkamah Agung yang sejatinya telah menimbulkan permasalahan dalam hal teoritis serta membingungkan dikalangan para penegak hukum, hal ini karena sesuai asas hukum yang berlaku tidak memperkenankan peraturan yang lebih rendah digunakan untuk mengesampingkan peraturan yang lebih tinggi (lex superior derogate legi inferior).

Dalam penegakan hukum sendiri terdapat tiga tujuan hukum yaitu terciptanya kepastian hukum, kemanfaatan, dan keadilan didalam masyarakat. Dari ketiga nilai dasar dan tujuan hukum tersebut terdapat suatu ketegangan atau benturan satu dengan yang lainnya, sehingga para pemerhati hukum menyatakan bahwa di antara ketiga nilai dasar hukum tersebut tentunya mempunyai tuntutan yang berbeda satu sama lainnya. Dengan kata lain apabila kepastian hukum yang diutamakan sebagai nilai maka secara tidak langsung dapat menggeser nilai-nilai keadilan dan manfaat.

Apabila terjadi benturan antara nilai-nilai dasar hukum itu, sudah barang tentu kita harus menggunakan asas prioritas sebagai jalan tengahnya dimana hal yang diutamakan yaitu nilai keadilan, kegunaan atau kemanfaatan dan terakhir adalah kepastian hukum. Ini menunjukkan bahwa penempatan nilai keadilan itu sesungguhnya lebih utama daripada nilai kemanfaatan dan nilai kepastian hukum, serta dapat pula nilai kepastian hukum ditempatkan dibawah nilai kemanfaatan hukum.

\section{SIMPULAN DAN SARAN}

\section{Simpulan}

Pengaturan terhadap langkah hukum peninjauan kembali pada sistem hukum di Indonesia diatur dalam berbagai peraturan perundang- undangan yaitu Undang-undang Nomor 8 tahun 1981 tentang Kitab Undang-undang Hukum Acara Pidana, Undang-undang Nomor 3 Tahun 2009 tentang Mahkamah Agung dan terakhir pada SEMA Nomor 7 Tahun 2014 tentang Peninjauan Kembali Dalam Perkara Pidana. Kedua, Pengajuan peninjauan kembali saat ini adalah mengacu pada ketentuan pada Surat Edaran Mahkamah Agung Republik Indonesia No. 7 Tahun 2014 tentang Peninjauan Kembali Dalam Perkara Pidana.

\section{Saran}

Pemerintah dan lembaga pembentuk undang-undang sudah saatnya membuat peraturan dalam bentuk undang-undang khusus mengatur tentang peninjauan kembali agar tercipatnya sistem hukum yang tertib kemudai dalam pelaksanaan hukum baiknya lembaga peradilan mengedepankan unsur keadilan dan kemanfaatan ketimbang unsur keadilan dalam menyelesaikan permasalahan. 


\section{DAFTAR PUSTAKA}

Hamzah, A. (2001). Hukum Acara Pidana Indonesia edisi Revisi. Sinar Grafika.

Kalsen, H. (2010). General Theory of Law and State (Teori Umum tentang Hukumdan Negara). Nusa Media.

Kusumawati, B. I. J. E. N. P. N. (2015). Analisis Yuridis Pertimbangan Mahkamah Agung Menerima Pengajuan Peninjauan Kembali Perkara Pidana oleh Jaksa. Jurnal Verstek, 3(1).

Litbang, T. P. P. (2006). Problematika Penerimaan Peninjauan kembali Dan Grasi Dalam Penegakan Hukum. Puslitbang Kejagung RI.

Mamudji, S. S. S. (2007). Penelitian Hukum Normatif-Suatu Tinjauan Singkat. Rajawali Press.

Reksodiputro, M. (1994). Kriminologi dan Sistem Peradilan Pidana, Kumpulan Karangan Buku Kedua, Pusat pelayanan dan Pengabdian Hukum. Lembaga Kriminologi UI.

Sunggono, B. (2013). Metode Penelitian Hukum, Cetakan Keempat Belas. PT. Raja Grafindo Persada. Zoelva, H. (2009). Kewenangan MK dalam Constitutional Complaint and Constitutional Questio,. MK Republik Indonesia. 